\title{
Purification, Purity, and Freezing Points of 31 Hydrocarbons of the API-NBS Series ${ }^{1}$
}

\author{
By Augustus R. Glasgow, Jr., Evelyn T. Murphy, ${ }^{2}$ Charles B. Willingham, and \\ Frederick D. Rossini
}

\begin{abstract}
This report describes the purification and determination of freezing points and purity of 31 hydrocarbons of the API-NBS series, including 2 pentanes, 5 hexanes, 2 heptanes, 1 octane, 3 alkylcyclopentanes, 3 alkylcyclohexanes, and 15 alkylbenzenes.
\end{abstract}

\section{Introduction}

In May 1943, the Advisory Committee for the American Petroleum Institute Hydrocarbon Research Committee, operating the API Hydrocarbon Research Project ${ }^{3}$ at the Ohio State University, requested the American Petroleum Institute Research Project 6 at the National Bureau of Standards to begin purification of a series of hydrocarbon compounds of the highest practicable purity, under the label API-NBS hydrocarbons. This work was begun July 1 , 1943 , with a large number of compounds of relatively high purity being supplied by the API

\footnotetext{
1 This investigation was performed at the National Bureau of Standards as part of the work of the American Petroleum Institute Research Project 6 on the Analysis, Purification, and Properties of Hydrocarbons.

2 Research Associate on the American Petroleum Institute Research Project 6 at the National Bureau of Standards.

3 On September 1, 1944, this project became the American Petroleum Research Project 45 on the "Synthesis and Properties of Hydrocarbons of LowMolecular Weight", with Cecil E. Boord continuing as Supervisor and Robert F. Marschner becoming chairman of the Advisory Committee. D. P. Barnard was chairman of the former API Hydrocarbon Research Committee, which was merged on September 1, 1944, with the API Advisory Committee on Fundamental Research on the Composition and Properties of Petroleum, of which J. Bennett Hill was chairman.
}

Hydrocarbon Research Project for further purification. During the first year of operation, the purification of 31 compounds of the API-NBS series was completed. This report describes the purification and determination of freezing points and purity of these hydrocarbons, which are being made available on loan to qualified investigators for the measurement of needed properties. ${ }^{4}$

4 The allocation of these samples, by loan to qualified investigators for the measurement of needed properties, is handled by the Advisory Committee for the API Research Project 44 at the National Bureau of Standards on the "Collection, Analysis, and Calculation of Data on the Properties of Hydrocarbons" (W. E. Kuhn, chairman, Otto Beeck, Gustav Egloff, and S. Kurtz, Jr., with F. D. Rossini as Supervisor of the Project).

\section{Contents}

Page

I. Introduction

II. Materials and purification _............... 142

III. Freezing points and purity

IV. References_......... 145 


\section{Materials and Purification}

The starting materials were supplied as follows: ${ }^{5}$ By the API Hydrocarbon Research Project, now the API Research Project 45 on the "Synthesis and Properties of Hydrocarbons of LowMolecular Weight", at the Ohio State University, under the supervision of Cecil E. Boord: Cyclopentane, ethylcyclopentane (A), methylcyclohexane (approximately half), ethylcyclohexane, $m$-xylene (A), $p$-xylene (A), 1,3,5-trimethylbenzene, $n$-butylbenzene (A), isobutylbenzene (A), secbutylbenzene (A), and tert-butylbenzene (A).

By the Barrett Division of the Allied Chemical and Dye Corporation: Cyclohexane, methylcyclohexane (approximately half).

By the Standard Oil Co. (Indiana) and the M. W. Kellogg Co.: 2,3-Dimethylbutane.

By the General Motors Corporation: 2,2,3Trimethylbutane.

By the Houdry Process Corporation: Methylcyclopentane.

By the Humble Oil \& Refining Co.: Toluene.

By the Monsanto Chemical Co.: Ethylbenzene, isopropylbenzene.

By the Standard Oil Development Co.: o-Xylene (A).

By the Dow Chemical Co.: n-Propylbenzene (A).

By the API Research Project 6: $n$-Pentane, isopentane, $n$-hexane, 2-methylpentane, 3-methylpentane, 2,2-dimethylbutane, $n$-heptane, 2,2,4trimethylpentane, benzene, 1,2,3-trimethylbenzene (A), 1,2,4-trimethylbenzene (A). In this group, the stocks of the following compounds were obtained by purchase of commercially available materials: $n$-Pentane, isopentane, and 2,2-di-

\footnotetext{
A letter A following the name of a compound indicates that subsequently a new and usually slightly purer sample (B) has been or is being prepared, the description of which will appear in a later report.
}

methylbutane from the Phillips Petroleum Co.; $n$-heptane from the Westvaco Chlorine Products Co.; 2,2,4-trimethylpentane from the Rohm \& Hass Co.; benzene, from the Koppers Co.

Information regarding the volume of the starting material, details of the purification by distillation, and volume of the selected "best" lot, is given in table 1. Additional details of the distilling columns are given in preceding reports [1,2].* In addition to the purification by distillation, the benzene, $m$-xylene, and $p$-xylene were subjected to a purification by crystallization with centrifuging by B. J. Mair and A. J. Streiff of this laboratory [7].

For this group of 31 compounds, time was not available for the detailed examination of the purity, by measurement of freezing points, of the distillate as a function of its volume, ${ }^{6}$ and the best sample was taken as an appropriately selected "heart" cut (not necessarily the middle part of the distillate) having the volume given in the last column of table 1. This volume may be compared for each compound with the volume of the starting material given in the third column. The heart cut was selected largely on the basis of refractive index and boiling point, although, as will be shown in the next report on the purification of API-NBS hydrocarbons [3], this is a procedure which frequently results in the discarding of the best material. Each final lot was filtered through silica gel [4] to remove water and nonhydrocarbon impurities.

\footnotetext{
*Figures in brackets indicate the literature references at the end of this paper.

In the next report on the purification of API-NBS and API-Standard hydrocarbons, in connection with the cooperative program of the National Bureau of Standards and the American Petroleum Institute on Standard Samples of hydrocarbons, a procedure will be described wherein enough freezing points are measured to determine the purity of the distillate as a function of its volume [3].
} 
TABLE 1.-Information on the starting materials and purification

\begin{tabular}{|c|c|c|c|c|c|c|c|c|}
\hline \multirow[b]{2}{*}{ Compound } & \multirow[b]{2}{*}{$\begin{array}{l}\text { Starting material pro- } \\
\text { vided by laboratory b }\end{array}$} & \multicolumn{6}{|c|}{ Distillation • } & \multirow[b]{2}{*}{$\begin{array}{c}\text { Volume } \\
\text { of } \\
\text { selected } \\
\text { sample }\end{array}$} \\
\hline & & Volume & Kind & $\begin{array}{l}\text { Azeotrope-forming } \\
\text { substance if used } ?\end{array}$ & Still No. & $\begin{array}{l}\text { Number } \\
\text { of theo- } \\
\text { retical } \\
\text { plates at } \\
\text { total } \\
\text { reflux } \\
\text { (approx.) }\end{array}$ & $\begin{array}{c}\text { Reflux } \\
\text { ratio } \\
\text { (approx.) }\end{array}$ & \\
\hline PARAFFINS & & & & & & & & \\
\hline$n$-Pentane & APIRP 6 & 2.8 & Regular....... & & $\mathrm{D}$ & 100 & $100 / 1$ & 370 \\
\hline 2-Methylbutane (isopentane) -- & APIRP 6 & 2.8 & - & - & $\mathrm{D}$ & 100 & $100 / 1$ & 370 \\
\hline$n$-Hexane_......................... & APIRP $6 \ldots$ & $\begin{array}{l}1.2 \\
1.2\end{array}$ & Azeotropic.......... & Methanol.. & $\begin{array}{c}\mathrm{E} \\
\mathrm{M}\end{array}$ & $\begin{array}{l}100 \\
100\end{array}$ & $\begin{array}{l}100 / 1 \\
100 / 1\end{array}$ & 375 \\
\hline 2-Methylpentane & APIRP 6... & 1.9 & do do & -... do do...... & $\mathrm{E}$ & 100 & $100 / 1$ & 325 \\
\hline 3-Methylpentane.... & APIRP $6 \ldots$ & $\begin{array}{l}0.50 \\
1.4\end{array}$ & -.... do & -.......... & $\mathrm{Q}$ & 100 & $120 / 1$ & 255 \\
\hline 2,2-Dimethylbutane. & APIRP 6 & 2.8 & Regular...... & & $\mathrm{F}$ & 100 & $100 / 1$ & 290 \\
\hline 2,3-Dimethylbutane...... & Std. (Ind.); Kellogg.-- & 1.9 & Azeotropic. - & Methanol & M & 100 & $100 / 1$ & 275 \\
\hline$n$-Heptane........... & APIRP 6 & 1.0 & - do do & Ethanol & 8 & 130 & $145 / 1$ & 380 \\
\hline 2,2,3-Trimethylbutane & General Motors......... & 1.3 & - do do & Methanol .......... & 9 & 135 & $165 / 1$ & 360 \\
\hline 2,2,4-Trimethylpentane & APIRP 6 & 2.4 & 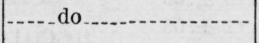 & Ethanol ............ & 10 & 135 & $165 / 1$ & 350 \\
\hline \multicolumn{9}{|l|}{ ALKYLCYCLOPENTANES } \\
\hline Cyclopentane... & APIRP 45 ... & 0.80 & do & Methanol - & 2 & 100 & $135 / 1$ & 415 \\
\hline Methylcyclopentane....-. & Houdry & 1.8 & & do & $\mathrm{D}$ & 100 & $100 / 1$ & 380 \\
\hline Ethylcyclopentane (A) ...- & APIRP $45 \ldots$ & $\begin{array}{r}0.45 \\
.40\end{array}$ & do & ...... do & $\begin{array}{l}\mathrm{J} \\
\mathrm{P}\end{array}$ & $\begin{array}{l}125 \\
100\end{array}$ & $\begin{array}{l}100 / 1 \\
120 / 1\end{array}$ & 200 \\
\hline ALKYLCYCLOHEXANES & & & & & & & & \\
\hline Cyclohexane & Barrett & 2.7 & Regular & & $\mathrm{D}$ & 100 & $100 / 1$ & 400 \\
\hline Methylcyclohexane........ & Barrett, APIRP 45... & 1.1 & Azeotropic... & Ethanol & 8 & 130 & $145 / 1$ & 400 \\
\hline Ethylcyclohexane & APIRP 45 & 0.92 & - do & Cellosolve_................ & 9 & 135 & $165 / 1$ & 450 \\
\hline \multicolumn{9}{|l|}{ ALKYLBENZENES } \\
\hline Benzene.............. & APIRP 6 & .59 & Regular $\bullet .$. & & I & 125 & $100 / 1$ & 450 \\
\hline Toluene....... & Humble & .47 & - do $d o_{2}$ & 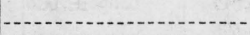 & $\mathbf{J}$ & 125 & $100 / 1$ & 330 \\
\hline Ethylbenzene & Monsanto ............ & .82 & Azeotropic & Methyl Cellosolve.... & $\mathrm{E}$ & 100 & $100 / 1$ & 330 \\
\hline 0 -Xylene (A) & Std. Oil Dev & .60 & Regular & 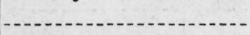 & $\bar{J}$ & 125 & $100 / 1$ & 280 \\
\hline$m$-Xylene (A) & APIRP 45 & .34 & Regular $\bullet . .$. & - & I & 125 & $100 / 1$ & 240 \\
\hline$p$-Xylene (A) & APIRP $45 \ldots$ & d. 60 & ..... do. $\bullet$ & - non & $\mathrm{I}$ & 125 & $100 / 1$ & 350 \\
\hline$n$-Propylbenzene (A) & Dow & .48 & ...................... & - & $\mathbf{J}$ & 125 & $100 / 1$ & 220 \\
\hline Iso-Propylbenzene & Monsanto & .80 & Azeotropic. - & Cellosolve & M & 100 & $100 / 1$ & 350 \\
\hline 1,2,3-Trimethylbenzene (A) _... & APIRP $6 \ldots$ & .45 & ................ & Methyl Carbitol...... & 9 & 135 & $165 / 1$ & 190 \\
\hline 1,2,4-Trimethylbenzene (A) & APIRP 6 & .89 & -.... do & - do & 10 & 135 & $165 / 1$ & 400 \\
\hline 1,3,5-Trimethylbenzene & APIRP $45 \ldots$ & 1.2 & ..... do ..... & - do do......... & 8 & 130 & $145 / 1$ & 260 \\
\hline$n$-Butylbenzene (A) & APIRP $45 \ldots$ & 0.94 & ..... do & ..... do & 8 & 130 & $145 / 1$ & 260 \\
\hline Iso-Butylbenzene (A) & APIRP $45 \ldots$ & 1.1 & ..... do do..... & - do do & 7 & 130 & $145 / 1$ & 240 \\
\hline sec-Butylbenzene (A) & APIRP $45 \ldots$ & 1.1 & ..... do & . do & 7 & 130 & $145 / 1$ & 300 \\
\hline tert-Butylbenzene (A) & APIRP $45 \ldots$ & 1.1 & -..... do & -... do & 8 & 130 & $145 / 1$ & 360 \\
\hline
\end{tabular}

- A letter A following the name of a compound indicates that subsequently a new and usually slightly purer sample (B) has been or is being prepared, the description of which will appear in a later report.

b The abbreviations represent the following laboratories:

APIRP 45; American Petroleum Institute Research Project 45 (formerly the American Petroleum Institute Hydrocarbon Research Project) on the "Synthesis and Properties of Hydrocarbons of Low Molecular Weight," at the Ohio State University, Columbus, Ohio; C. E. Boord, Supervisor.

APIRP 6; American Petroleum Institute Research Project 6 on the "Analysis, purification, and properties of hydrocarbons", at the National Bureau of Standards, Washington, D. C.; F. D. Rossini, Supervisor.

Barrett; Barrett Division of the Allied Chemical \& Dye Corporation, New York, N. Y.

Dow; Dow Chemical Co., Midland, Mich.
General Motors; General Motors Corporation, Detroit, Mich. Houdry; Houdry Process Corporation, Marcus Hook, Pa.

Humble; Humble Oil \& Refining Co., Houston, Texas.

Kellogg; M. W. Kellogg Co., New York, N. Y.

Monsanto; Monsanto Chemical Co., Dayton, Ohio.

Std. Oil Dev.; Standard Oil Development Co., Elizabeth, N. J.

Std. (Ind.); Standard Oil Co. (Indiana), Whiting, Ind.

- See references [1] and [2] for further details.

d Three separate distillations of this volume were made.

- See text regarding additional purification by crystallization.

\& Methyl Cellosolve is ethylene glycol monomethyl ether; Cellosolve is ethylene glycol monoethyl ether; methyl Carbitol is diethylene glycol monomethyl ether. 


\section{Freezing Points and Purity}

For each of the compounds except 3-methylpentane, which failed to yield crystals, the freezing point of the actual sample was determined from

TABLE 2.-Freezing points and purity of 31 API-NBS hydrocarbons

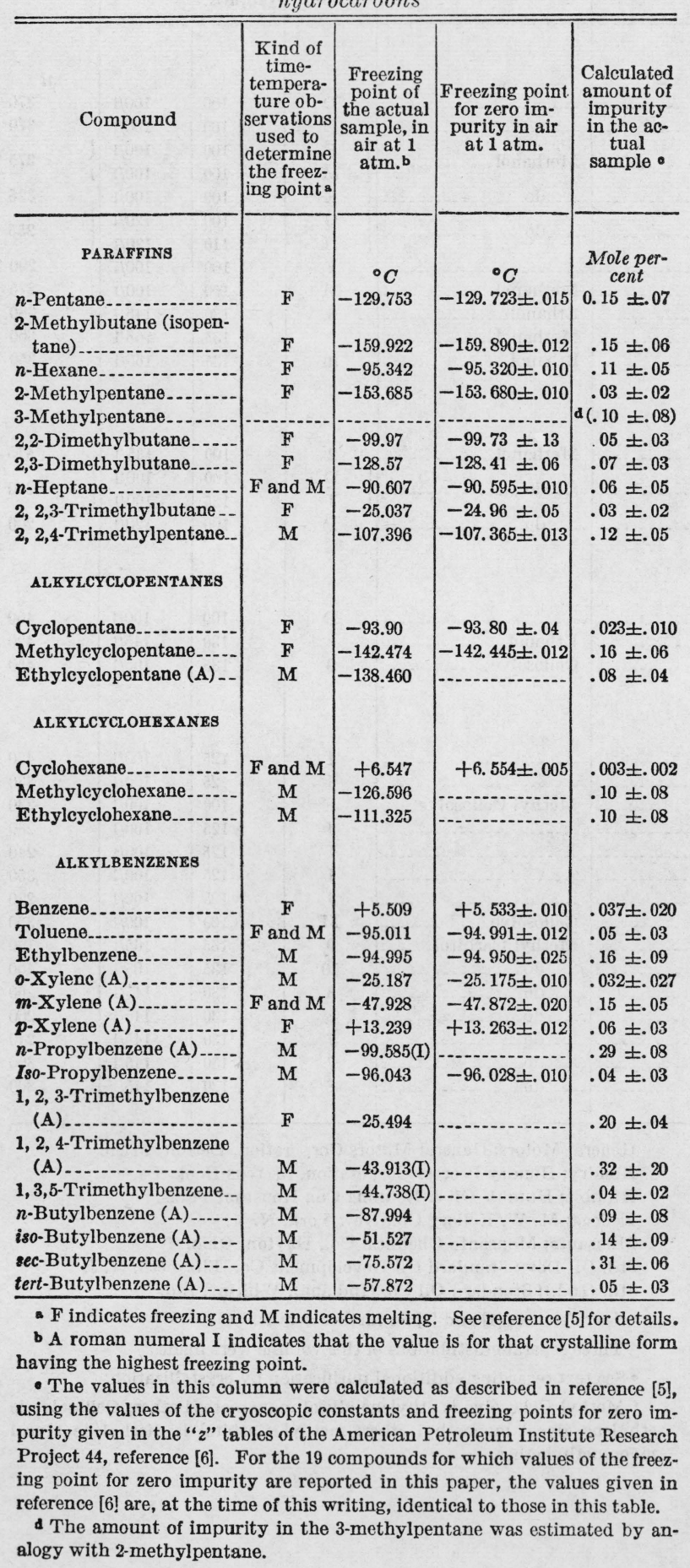

time-temperature freezing or melting curves obtained with the apparatus and procedure recently described [5]. From these data, the freezing point for zero impurity was determined according to the procedure described in reference [5].

For benzene and $p$-xylene, in which the solubility of water is quite appreciable, and for which the freezing points are above that of water, the sample was introduced, by filtration through a small tube containing silica gel, directly into the freezing tube with substantially no contact with the air of the room after water in the sample was removed by the silica gel. Dry air was kept flowing into the top of the freezing tube during the experiment.

The purity of the actual sample was calculated according to the method described in section VIII of reference [5], using the values of the freezing point of the actual sample and the freezing point for zero impurity determined in this investigation, (except as otherwise indicated), together with values of the cryoscopic constants obtained from the " $z$ " tables of the American Petroleum Institute Research Project 44 [6] or from unpublished data from references [3] and [8]. For each of the compounds except 3-methylpentane, table 2 indicates whether freezing or melting experiments were used, and gives the values of the freezing point of the actual sample, the freezing point for zero impurity where determined in this investigation, and the calculated amount of impurity. The amount of impurity in the 3-methylpentane was estimated by analogy with 2-methylpentane. From the manner of preparation and purification of these compounds, it is believed that the impurities in most cases are substantially all close-boiling isomers.

Grateful acknowledgment is made to the following persons and laboratories for supplying the materials for purification listed in table 1: C. E. Boord, Supervisor of the American Petroleum Institute Research Project 45 (formerly the API Hydrocarbon Research Project) at the Ohio State University, Columbus, Ohio; W. J. Sweeney, Standard Oil Development Co., New York, N. Y.; T. A. Boyd and W. G. Lovell, General Motors Corporation, Detroit, Mich.; E. A. Smith, Houdry Process Corporation, Marcus Hook, Pa.; R. R. Dreisbach, Dow Chemical Co., Midland, Mich.; 
Barrett Division of the Allied Chemical \& Dye Corporation, New York, N. Y.; Standard Oil Co. (Indiana), Whiting, Ind.; M. W. Kellogg Co., New York, N. Y.; Monsanto Chemical Co., Dayton, Ohio; Humble Oil \& Refining Co., Houston, Tex.
Especial acknowledgment is due George Calingaert, formerly chairman of the subcommittee on purification and properties under the API Hydrocarbon Research Project, who made the arrangements for starting the series of API-NBS hydrocarbons.

\section{References}

[1] C. B. Willingham and F. D. Rossini, J. Resarch NBS 37, 15, (194.6) RP 1724.

[2] A. F. Forziati, A. R. Glasgow, Jr., C. B. Willingham, and F. D. Rossini, J. Research NBS 36, 129 (1946) RP 1695.

[3] A. J. Streiff, E. T. Murphy, C. B. Willingham, V. A. Sedlak, and F. D. Rossini, National Bureau of Standards. American Petroleum Institute Research Project 6. Unpublished.

[4] B. J. Mair and A. F. Forziati, J. Research NBS 32, 151 (1944) RP 1582.

[5] A. R. Glasgow, Jr., A. J. Streiff, and F. D. Rossini, J. Research NBS 35, 355 (1945) RP 1676.
[6] American Petroleum Institute Research Project 44 at the National Bureau of Standards. Tables $1 z, 2 z$, $3 z$, and $5 z$. Heat and entropy of fusion, freezing points, and cryoscopic constants. Dec. 31,1944 , to Aug. 31, 1945.

[7] B. J. Mair and A. J. Streiff, J. Research NBS 27, 343 (1941) RP 1423.

[8] A. J. Streiff, E. T. Murphy, J. C. Cahill, H. F. Flanagan, V. A. Sedlak, C. B. Willingham, and F. D. Rossini, National Bureau of Standards. American Petroleum Institute Research Project 6. Unpublished.

Washington, April 3, 1946. 